\title{
ANALISIS KESALAHAN EJAAN PADA BERITA UTAMA SERAMBI INDONESIA EDISI JANUARI 2020
}

\author{
oleh \\ Ifutya Warnisa, Syahriandi*, Trisfayani \\ *Dosen Program Studi Pendidikan Bahasa Indonesia, FT Universitas Malikussaleh \\ surel: syahriandi@unimal.ac.id
}

\begin{abstract}
ABSTRAK
Penelitian ini bertujuan untuk mendeskripsikan kesalahan ejaan pada berita utama Serambi Indonesia edisi Januari 2020. Penelitian ini dilakukan dengan menggunakan pendekatan kualitatif dengan jenis penelitian deskriptif kualitatif. Data yang dianalisis berjumlah 29 terbitan. Teknik pengumpulan data yang digunakan dalam penelitian ini adalah teknik baca dan catat. Teknik analisis data pada penelitian ini menggunakan empat tahap, yaitu (1) mengumpulkan sampel dan mengidentifikasi kesalahan, (2) mengklasifikasi data, (3) mendeskripsikan kesalahan, serta (4) mengevaluasi dan menyimpulkan kesalahan. Hasil penelitian terdapat 444 kesalahan ejaan berita utama dan ditemukan empat jenis kesalahan ejaan. Kesalahan-kesalahan tersebut berupa kesalahan pemakaian huruf, ditemukan sebanyak 138 kesalahan, penulisan kata ditemukan sebanyak 126 kesalahan, pemakaian tanda baca ditemukan sebanyak 167 kesalahan, dan penulisan unsur serapan sebanyak 13 kesalahan.
\end{abstract}

Kata Kunci: ejaan, Serambi Indonesia, berita utama 


\section{PENDAHULUAN}

Penelitian ini mengkaji kesalahan ejaan pada berita utama Serambi Indonesia edisi Januari 2020. Penelitian ini menarik untuk dilakukan dengan beberapa alasan berikut. Pertama, terdapat kesalahan penggunaan bahasa Indonesia yang baik dan benar pada media massa di Aceh, khususnya media cetak. Salah satu bentuk kesalahan penulisan kaidah berbahasa Indonesia pada media cetak terdapat dalam surat kabar harian Serambi Indonesia.

Kedua, kesalahan-kesalahan tersebut dapat memengaruhi masyarakat, khususnya masyarakat Aceh. Bahkan, banyak masyarakat Aceh menjadikan penulisan ejaan pada surat kabar tersebut sebagai pedoman dalam penulisan ejaan bahasa Indonesia.

Ketiga, di Aceh, terdapat dua media cetak yang terverifikasi administrasi dan faktualnya oleh Dewan Pers, yaitu Serambi Indonesia dan Rakyat Aceh (Dialeksis.com). Serambi Indonesia menjadi salah satu media massa yang paling banyak pengaruhnya karena lebih dikenal dan tersebar di Provinsi Aceh. Dengan begitu, segala kesalahan dalam teknik penulisan haruslah dihindari. Keempat, Serambi Indonesia sudah memilki editor sebelum penerbitan, tetapi kesalahan ejaan masih juga terjadi hingga saat ini. Kesalahan ejaan terlihat lebih banyak ditemukan di media Serambi Indonesia, ditambah lagi, surat kabar ini sudah banyak dijadikan sebagai bahan penelitian bahasa. Oleh karena itu, penulis menganalisis kesalahan ejaan pada surat kabar harian Serambi Indonesia.

Ketentuan lebih lanjut tentang penggunaan bahasa Indonesia diatur dalam Peraturan Presiden Nomor 63 Tahun 2019. Salah satu isi Perpres 63 Tahun 2019 adalah Bab II tentang Ketentuan Penggunaan Bahasa Indonesia, pada 30 September 2019, Bagian Kesatu Umum, Pasal 2. Adapun isi dari Perpres
63 Tahun 2019 tersebut adalah sebagai berikut.

1) Penggunaan bahasa Indonesia harus memenuhi kriteria bahasa Indonesia yang baik dan benar. 2) Bahasa Indonesia yang baik sebagaimana dimaksud pada Ayat (1) merupakan bahasa Indonesia yang digunakan sesuai dengan konteks berbahasa dan selaras dengan nilai sosial masyarakat. 3) Bahasa Indonesia yang benar sebagaimana dimaksud pada Ayat (1) merupakan bahasa Indonesia yang digunakan sesuai dengan kaidah bahasa Indonesia. 4) Kaidah bahasa Indonesia sebagaimana dimaksud pada Ayat (3) meliputi kaidah tata bahasa, kaidah ejaan, dan kaidah pembentukan istilah.

Selanjutnya, berdasarkan Perpres 63 Tahun 2019 tentang Penggunaan Bahasa Indonesia Pasal 41, bahasa Indonesia wajib digunakan dalam informasi melalui media massa baik dari media elektronik maupun media cetak. Artinya, semua media massa haruslah berpedoman kepada kaidah-kaidah kebahasaan dalam setiap penulisan. Oleh sebab itu, penelitian ini menarik untuk dikaji. Dalam penelitian ini, penulis hanya menjelaskan mengenai kesalahan ejaan, yaitu berupa kesalahan pemakaian huruf, penulisan kata, penggunaan tanda baca, dan penulisan unsur serapan pada berita utama Serambi Indonesia edisi Januari 2020.

\section{LANDASAN TEORI Pengertian Ejaan}

Berdasarkan etimologi, kata ejaan berasal dari kata eja, yaitu melafalkan huruf-huruf atau lambang bunyi bahasa satu demi satu. Ejaan adalah kaidah cara menggambarkan bunyi-bunyi (kata, kalimat, dan sebagainya) dalam bentuk tulisan (huruf-huruf), serta penggunaan tanda baca (KBBI, 2014:353). Slamet (2014:85) menyatakan bahwa ejaan didasarkan semata-mata pada konvensi. Artinya, lahirnya ejaan tersebut adalah dari hasil persetujuan pemakai bahasa 
yang bersangkutan. Ejaan tersebut disusun oleh panitia yang terdiri dari beberapa ahli bahasa, kemudian disahkan atau diresmikan oleh pemerintah. Masyarakat pemakai bahasa tersebut mematuhi apa yang telah ditetapkan itu.

\section{Fungsi Ejaan}

Azwardi (dalam Lasiratan, 2019:37) menyatakan bahwa fungsi ejaan adalah (a) sebagai landasan pembakuan tata bahasa, (b) sebagai landasan pembakuan kosakata dan peristilahan, (c) sebagai alat penyaring masuknya unsurunsur bahasa asing ke dalam bahasa Indonesia, dan (d) untuk membantu pembaca dalam memahami dan mencerna informasi yang disampaikan cecara tertulis.

Dari penjelasan tersebut, dapat disimpulkan bahwa fungsi ejaan berupa 1) sebagai landasan pembakuan tata bahasa, kosakata, dan peristilahan, 2) sebagai alat penyaring unsur bahasa asing, 3) sebagai panduan bagi pembaca, dan 4) dapat membantu pembaca dalam memahami penulisan yang baik dan benar. Ejaan dapat mengalami perubahan sesuai dengan perkembangan zaman, umumnya ejaan bahasa Indonesia dapat dikatakan mampu mengikuti zaman yang berkembang.

\section{Pedoman Umum Ejaan Bahasa Indonesia (PUEBI)}

Lembaga Bahasa dan

Kesusastraan telah berganti nama menjadi Pusat Pembinaan dan Pengembangan Bahasa, guna menyusun program pembakuan bahasa Indonesia secara menyeluruh. Pada tahun 1972, surat keputusan Menteri Pendidikan dan Kebudayaan tanggal 20 Mei 1972, No. 03/A.I/72, diresmikanlah aturan ejaan baru dengan nama Ejaan yang Disempurnakan (EYD). Departemen Pendidikan dan Kebudayaan menyebarkan buku kecil yang berjudul Pedoman Umum Ejaan yang
Disempurnakan (PUEYD) sebagai patokan pemakaian ejaan (Puspaningrum, 2015:17).

Pada tahun 2016, berdasarkan keputusan Menteri Pendidikan dan Kebudayaan, Dr. Anis Baswedan, Pedoman Umum Ejaan yang Disempurnakan (PUEYD) diganti dengan Pedoman Umum Ejaan Bahasa Indonesia (PUEBI). Penyempurnaan naskahnya disusun oleh Pusat Pembinaan dan Pengembangan Bahasa. PUEBI tahun 2016 berisi (a) pemakaian huruf, (b) penulisan kata, (c) pemakaian tanda baca, dan (d) penulisan unsur serapan (Fitriani, 2017:15). Oleh sebab itu, saat ini EYD telah berganti menjadi PUEBI.

\section{Pengertian Berita Utama}

Berita utama didefinisikan oleh Djunaedy (dalam Khikmah, 2017:35) sebagai suatu berita yang dianggap paling layak untuk dimuat di halaman depan, dengan judul yang menarik perhatian pembaca dan menggunakan tipe huruf lebih besar dari suatu surat kabar. Soehoet (dalam Amiluddin, 2018:18-19) juga memberikan definisi tentang berita utama. Menurutnya, berita utama merupakan berita yang menurut penilaian redaktur surat kabar tersebut adalah berita terpenting dari semua berita yang disajikan dalam surat kabarnya hari itu. Oleh sebab itu, diberikannya tempat utama yang mudah dibaca, yaitu halaman pertama pada bagian paling atas sebelah kiri dari surat kabar tersebut.

Hal ini juga sesuai dengan pendapat Loupatty dkk. (2019:1-3) bahwa dalam sebuah surat kabar, halaman depan atau yang disebut dengan headline news adalah yang paling penting dan merupakan hal yang pertama kali menjadi fokus perhatian dari pembaca ketika melihat surat kabar. Headline news merupakan berita utama atau berita yang paling dianggap viral dan banyak dibicarakan masyarakat, kemudian ditempatkan pada halaman bagian depan 
surat kabar. Salah satu fungsi dari berita utama adalah menyediakan intisari berita atau berita penting dan banyak dibicarakan masyarakat.

\section{Syarat Penulisan Bahasa dalam Berita (Media Massa)}

Penerbitan informasi pada media massa memiliki ketentuan berupa syaratsyarat dalam penulisan. Sebagaimana dicantumkan pada Perpres Nomor 63 Tahun 2019 pada Bagian Kelima Belas mengenai Informasi Melalui Media Massa, Pasal 41 adalah sebagai berikut.

1. Bahasa Indonesia wajib digunakan dalam informasi melalui media massa.

2. Media massa sebagaimana dimaksud pada ayat (1) meliputi:

a. media massa cetak; dan

b. media massa elektronik.

3. Dalam hal diperlukan untuk menyampaikan informasi yang mempunyai tujuan khusus atau sasaran khusus mengenai kekhasan tradisi daerah, media massa dapat menyampaikan infomasi dalam bahasa daerah.

4. Dalam hal diperlukan untuk menyampaikan informasi yang mempunyai tujuan khusus atau sasaran khusus untuk pelayanan publik internasional, media massa dapat menyampaikan infomasi dalam bahasa asing.

Berdasarkan hal tersebut, maka informasi yang disampaikan melalui media massa wajib menggunakan bahasa Indonesia. Hal ini berkaitan dengan Perpres 63 Tahun 2019 Pasal 2 mengenai Ketentuan Penggunaan Bahasa Indonesia yang telah disebutkan sebelumnya, yaitu pada Ayat (1) tentang "Penggunaan bahasa Indonesia harus memenuhi kriteria bahasa Indonesia yang baik dan benar"; dan pada Ayat (4) mengenai "Kaidah bahasa Indonesia sebagaimana dimaksud pada Ayat (3) meliputi kaidah tata bahasa, kaidah ejaan, dan kaidah pembentukan istilah". Oleh sebab itu, jelas bahwasanya berita-berita maupun informasi lainnya pada media massa diharapkan dapat mengikuti syarat atau ketentuan penggunaan bahasa Indonesia dalam penulisan.

\section{Pengertian Analisis Kesalahan Berbahasa}

Analisis kesalahan berbahasa adalah kegiatan pengkajian segala aspek penyimpangan berbahasa itu sendiri. Dulay dkk. (dalam Sarwono, 2016:549) mengatakan bahwa kesalahan berbahasa adalah terjadinya penyimpangan kaidah dalam tindak berbahasa, baik lisan maupun tertulis. Johan dan Simatupang (2017:242 - 243) berpendapat bahwa kesalahan berbahasa secara sederhana dimaknai sebagai penggunaan bahasa, baik dilakukan secara lisan maupun tertulis yang menyimpang dari kaidah kebahasaan. Analisis kesalahan berbahasa dapat dipandang sebagai suatu proses dalam mengumpulkan, mengidentifikasi, mengklasifikasi, menjelaskan, dan mengevaluasi kesalahan berbahasa.

\section{Jenis-Jenis Kesalahan Berbahasa}

Setyawati (dalam Puspaningrum, 2015:14-15) mengategorikan kesalahan berbahasa, yaitu (a) kesalahan fonologi, (b) kesalahan morfologi, (c) kesalahan sintaksis, (d) kesalahan semantik, (e) kesalahan wacana, dan (f) kesalahan berbahasa penerapan kaidah buku Pedoman Umum Ejaan Bahasa Indonesia yang Disempurnakan.

Senada dengan penelitian tersebut, Tarigan (dalam Fitriani, 2017:11-13) mengatakan bahwa ada empat jenis kesalahan berbahasa Indonesia, yaitu (a) kesalahan fonologi, (b) kesalahan morfologi, (c) kesalahan sintaksis, dan (d) kesalahan leksikon.

Berdasarkan penjelasan tersebut, dapat disimpulkan bahwa jenis-jenis kesalahan berbahasa terdiri dari (a) kesalahan fonologi, (b) kesalahan morfologi, (c) kesalahan sintaksis, dan (d) kesalahan leksikon-semantik. 


\section{METODE PENELITIAN}

Penelitian ini menggunakan pendekatan kualitatif. Pendekatan kualitatif adalah metode penelitian yang digunakan untuk meneliti pada kondisi objek yang alamiah, data yang diperoleh cenderung kepada data kualitatif, analisis data bersifat kualitatif, dan hasil penelitian kualitatif bersifat untuk memahami makna, memahami keunikan, dan mengonstruksi fenomena (Sugiyono, 2018:9-10).

Selanjutnya, jenis penelitian yang digunakan adalah deskriptif kualitatif. Penelitian deskriptif kualitatif adalah jenis penelitian yang tidak terikat, menganalisis dalam bentuk deskripsi (penjelasan) yang tidak berupa angka atau koefisien tentang hubungan suatu variabel (Ratna dalam Oktavia, 2018:80). Metode ini bertujuan untuk menganalisis dan memahami fenomena kebahasaan yang sedang diteliti, fokusnya pada kesalahan ejaan berupa pemakaian huruf, penulisan kata, pemakaian tanda baca, dan penulisan unsur serapan; dijelaskan dalam bentuk kata-kata, bukan menggunakan angkaangka.

Data dalam penelitian ini adalah kesalahan penulisan ejaan berupa huruf, kata, frasa, dan kalimat yang terdapat pada berita utama. Kesalahan-kesalahan ejaan tersebut meliputi kesalahan (1) pemakaian huruf, (2) penulisan kata, (3) pemakaian tanda baca, dan (4) penulisan unsur serapan. Ada pun sumber data dalam penelitian ini adalah berita utama Serambi Indonesia edisi Januari 2020 sebanyak 29 terbitan.

Terdapat dua teknik pengumpulan data dalam penelitian ini, penulis menggunakan teknik baca dan teknik catat. Penulis terlebih dahulu membaca sumber data, yaitu berita utama surat kabar harian Serambi Indonesia edisi Januari 2020 sebanyak 29 terbitan per harinya. Teknik baca dilakukan dengan seksama terhadap huruf, kata, frasa, tanda baca, dan kalimat yang terdapat di berita utama Serambi Indonesia edisi Januari 2020. Teknik ini dilakukan secara berulang-ulang untuk mendapatkan data yang akurat dan hasil yang maksimal. Selanjutnya, teknik catat merupakan teknik yang digunakan sebagai bentuk dokumentasi dari hasil membaca. Bentuk dokumentasi ini adalah secara tertulis. Pencatatan ini dilakukan untuk mengategorikan data berdasarkan kriteria kesalahan ejaan. Teknik catat juga digunakan sebagai teknik dalam pengumpulan data. Sudaryanto (dalam Prasetya, 2019:120) mengatakan bahwa teknik catat adalah teknik yang digunakan untuk mengungkapkan suatu permasalahan yang terdapat dalam suatu bacaan atau wacana. Oleh sebab itu, langkah selanjutnya yang penulis lakukan adalah mencatat hal-hal yang perlu dikaji dengan memperhatikan secara mendalam.

Teknik analisis data yang penulis lakukan merujuk pada pendapat Ardiana dan Yonohudiyono (dalam Rafiana, 2020:44 -45). Teknik analisis data dalam penelitian ini dilakukan dengan beberapa tahap, yaitu sebagai berikut.

1) Mengumpulan Sampel Data dan Mengidentifikasi Kesalahan

Data dikumpulkan ke dalam korpus data berdasarkan hasil dari membaca sumber data yaitu Serambi Indonesia edisi Januari tahun 2020 sebanyak 29 terbitan. Data yang dicari dalam penelitian ini yaitu mencari kesalahan ejaan pada surat kabar Serambi Indonesia edisi Januari tahun 2020.

2) Mengklasifikasikan Data

$\begin{array}{rrr} & \text { Mengklasifikasi } & \text { merupakan } \\ \text { sebuah } & \text { kegiatan } & \text { yang }\end{array}$ menggolongkan, menyusun, atau mengelompokkan data. Data yang dikelompokkan adalah berupa jenis kesalahan ejaan pada Serambi Indonesia edisi Januari tahun 2020.

3) Mendeskripsikan Kesalahan 
Peneliti menjelaskan jenis kesalahan ejaan pada Serambi Indonesia edisi Januari tahun 2020 yang telah dianalisis.

4) Mengevaluasi dan Menyimpulkan

Mengevaluasi dan menyimpulkan adalah tahap melakukan penilaian dan merumuskan data-data yang telah didapatkan dan dianalisis dari Serambi Indonesia edisi Januari tahun 2020.

\section{HASIL PENELITIAN}

Berdasarkan hasil penelitian dari 29 terbitan berita utama Serambi Indonesia edisi Januari 2020, ditemukan 444 kesalahan penulisan ejaan. Kesalahan-kesalahan tersebut adalah sebagai berikut.

1. Pemakaian huruf

Kesalahan pemakaian huruf ditemukan sebanyak 138 kesalahan atau sebesar $31 \%$.. Kesalahan ini terdiri dari huruf abjad (kesalahan/kekeliruan pengetikan), ditemukan sebanyak 20 kesalahan atau sebesar 14,5\%, huruf kapital ditemukan sebanyak 34 kesalahan atau sebesar 24,6\%, dan huruf miring ditemukan sebanyak 84 kesalahan atau sebesar $61 \%$.

2. Penulisan Kata

Kesalahan penulisan kata ditemukan sebanyak 126 kesalahan atau sebesar 28\%. Kesalahan ini terdiri dari kesalahan penulisan kata dasar, ditemukan sebanyak 30 kesalahan atau sebesar 24\%, kata berimbuhan ditemukan sebanyak 7 kesalahan atau sebesar 5,5\%, kata ulang ditemukan sebanyak 2 kesalahan atau sebesar $1,6 \%$, gabungan kata ditemukan sebanyak 3 kesalahan atau sebesar $2,4 \%$, pemenggalan kata ditemukan sebanyak 4 kesalahan atau sebesar 3,2\%, kata depan ditemukan sebanyak 1 kesalahan atau sebesar $0,8 \%$, partikel ditemukan sebanyak 5 kesalahan atau sebesar 4\%, singkatan dan akronim ditemukan sebanyak 71 kesalahan atau sebesar $56,3 \%$, serta angka dan bilangan ditemukan sebanyak 3 kesalahan atau sebesar $2,4 \%$.

3. Pemakaian Tanda Baca Kesalahan pemakaian tanda baca ditemukan sebanyak 167 kesalahan atau sebesar 38\%. Kesalahan ini terdiri dari kesalahan pemakaian tanda koma (,), ditemukan sebanyak 60 kesalahan atau sebesar $36 \%$, tanda hubung (-), ditemukan sebanyak 2 kesalahan atau sebesar $1,2 \%$, tanda pisah (-), ditemukan sebanyak 1 kesalahan atau sebesar $0,6 \%$, tanda petik tunggal ('...'), ditemukan sebanyak 1 kesalahan atau sebesar 0,6\%, garis miring (/), ditemukan sebanyak 98 kesalahan atau sebesar 59\%, dan tanda penyingkat atau apostrof ('), ditemukan sebanyak 5 kesalahan atau sebesar 3\%.

4. Penulisan Unsur Serapan

Kesalahan penulisan unsur serapan ditemukan sebanyak 13 kesalahan. Persentase kesalahan penulisan unsur serapan adalah sebesar $3 \%$.

\section{PENUTUP}

Berdasarkan hasil penelitian dari 29 terbitan harian Serambi Indonesia edisi Januari 2020, terdapat 444 kesalahan ejaan. Kesalahan-kesalahan tersebut berupa kesalahan pemakaian huruf, ditemukan sebanyak 138 kesalahan atau sebesar $31 \%$, penulisan kata ditemukan sebanyak 126 kesalahan atau sebesar 28\%, pemakaian tanda baca ditemukan sebanyak 167 kesalahan atau sebesar 38\%, dan penulisan unsur serapan sebanyak 13 kesalahan atau sebesar 3\%. Secara keseluruhan, kesalahan pemakaian tanda baca merupakan kesalahan terbanyak yang ditemukan di berita utama Serambi Indonesia edisi Januari 2020 dan kesalahan yang paling sedikit ditemukan adalah kesalahan penulisan unsur serapan. 
Pada penelitian ini, penulis menyampaikan saran sebagai berikut. (1) Disarankan kepada pihak editor Serambi Indonesia agar hendaknya diteliti kembali tulisan-tulisan yang telah diterima dan disunting sesuai dengan kaidah bahasa Indonesia. (2) Agar para jurnalis dan pembaca (pengirim tulisan) lebih memperhatikan tulisannya yang sesuai dengan kaidah bahasa Indonesia, khususnya mengenai ejaan. (3) Bagi peneliti selanjutnya, penelitian ejaan dapat diperluas, hal ini dikarenakan kesalahan ejaan masih banyak ditemukan dalam objek yang berbeda-beda. Penelitian ini juga dapat dijadikan sebagai referensi.

\section{DAFTAR PUSTAKA}

Amiluddin. 2018. "Analisis Bahasa Jurnalistik Berita Utama Harian Berita Kota Makassar (Edisi September 2017)". Skripsi, (Internet), (http://repositori.uinalauddin.ac.id /13126/1/AMILUDDIN50500113090-

JURNALISTIK.pdf). diakses tanggal 13 Oktober 2020.

Departemen Pendidikan Nasional. 2014. Kamus Besar Bahasa Indonesia Pusat Bahasa Edisi Keempat. Jakarta: Gramedia Pustaka Utama.

Fitriani, Erlina Rizky. 2017. "Analisis Kesalahan Berbahasa dalam Rubrik 'Wonosobo Ekspres' pada Harian Magelang Ekspres Edisi September 2016". Skripsi (Internet), (https://repository.usd.ac.id/11726 /2/134114006_full.pdf). diakses tanggal 19 Desember 2019.

FKIP Unimal. 2019. Pedoman Penulisan Skripsi. Aceh Utara: FKIP Unimal.
Johan, Gio Mohamad dan Yusrawati JR Simatupang. 2017. "Analisis Kesalahan Berbahasa Indonesia secara Sintaktis dalam Proses Diskusi Siswa Kelas IV SDN Miri”. Jurnal Visipena, (Internet), $\quad 8(2)$, (https://ejournal.bbg.ac.id/visipen a/article/view/408). diakses 13 Oktober 2020.

Kementerian Pendidikan dan Kebudayaan. 2016. Pedoman Umum Ejaan Bahasa Indonesia. Jakarta: Badan Pengembangan dan Pembinaan Bahasa. (http://badanbahasa.kemdikbud.go .id/lamanbahasa/sites/default/files/ PUEBI.pdf). diakses tanggal 7 Maret 2019.

Khikmah, Nurul. 2017. "Kesalahan Penggunaan Konjungsi pada Berita Utama dalam Surat Kabar Kedaulatan Rakyat Edisi Oktober 2016 dan Skenario Pembelajarannya di Kelas XII SMA". Skrips (Internet), (http://repository.umpwr.ac.id:808 0/handle/123456789/1195).

diakses tanggal 04 Maret 2020.

Lasiratan, Wati. 2019. "Analisis Kesalahan Penggunaan Ejaan pada Teks Dialog Siswa Kelas VIIC di SMP Negeri 4 Tolitoli." Jurnal Bahasa dan Sastra 4(3), (http://jurnal.untad.ac.id/jurnal/in dex.php/BDS/article/view/12223). diakses 04 Maret 2020.

Loupatty, Rachel M.R., Ferry V.I.A. Koagouw, dan Edmon R. Kalesaran. 2019. "Pengaruh Berita Utama (Headline News) Terhadap Pembaca Harian Kabar Timur di Kelurahan Lateri, Kecamatan Baguala, Kota 
Ambon". Jurnal, (Internet), 8(2), (https://ejournal.unsrat.ac.id/index .php/actadiurnakomunikasi/article /view/24555/2 253). diakses 13 Oktober 2020.

Oktavia, Wahyu. 2018. "Analisis Kesalahan Berbahasa Bidang Morfologi dalam WacanaJual Beli Daring di Instagram". Artikel Jala Bahasa (Internet), 14(1), (https://www.researchgate.net/pub lication/336390299_Analisis_Kes alahan_Berbahasa_pada_Bidang_ Morfologi_Terhadap_Jual_Beli_ Online_di_Instagram_The_Analy sis_of_Language_Error_in_the_Fi eld_of_Morphology_of_Online_B uying_and_Selling_in_Instagram/ link/5d9f33d7299bf116fe9b8a3b/ download). diakses tanggal 13 Oktober 2020.

Peraturan Presiden Nomor 63, Tahun 2019, Tentang Penggunaan Bahasa Indonesia. 2019. (Internet), (https://www.jogloabang.com/bud aya/perpres-63-2019-penggunaan bahasa-indonesia). diakses tanggal 04 Maret 2020.

Prasetya, Ady Dwi Achmad. 2019. "Analisis Kesalahan Ejaan pada Makalah MahasiswaSTKIP Al Hikmah Surabaya (Kajian Mata Kuliah Bahasa Indonesia)". Lingua Franca:

Jurnal Bahasa, Sastra, dan Pengajarannya, (Internet), 7(1), (http://ejournal.hikmahuniversity. ac.id/index.php/lentera/article/vie w/161). diakses 12 Oktober 2020.

Puspaningrum, Elisabeth Iga Woro Palupi. 2015. "Tipe-Tipe Kesalahan Berbahasa dalam Buku Teks Pelajaran Bahasa Indonesia Ekspresi Diri dan Akademik Kelas X Kurikulum
2013". Skripsi, (Internet), (https://repository.usd.ac.id/3855/ 2/101224028_full.pdf). diakses tanggal 25 Maret 2020.

Rafiana. 2020. "Analisis Kesalahan Ejaan pada Skripsi Mahasiswa Unimal". Skripsi. Aceh Utara: Universitas Malikussaleh.

Sarwono. 2016. "Kesalahan Penggunaan Bahasa pada Penulisan Papan Nama dan Spanduk di Provinsi Jambi”. Jurnal Ilmiah Kebahasaan \& Kesastraan, (Internet), 12(2), (https://jurnalmlangun.kemdikbud .go.id/jurnal/index.php/mlangun/a rticle/view/7/7). diakses 13 Oktober 2020.

Slamet, St. Y. 2014. Problematika Berbahasa Indonesia dan Pembelajarannya Edisi 2. Yogyakarta: Graha Ilmu.

Sugiyono. 2018. Metode Penelitian Kualitatif. Bandung: Alfabeta. 2019. "Media Terverifikasi di Aceh Masih Sedikit". (Internet), (https://dialeksis.com/analisis/med ia-terverifikasi-di-aceh-masihsedikit/). diakses tanggal 03 September 2020. 